\title{
Floating houses - an innovative idea for coastlines and river districts in times of global climate change
}

\author{
H. Stopp \& P. Strangfeld \\ Department of Building Physics, University of Applied Sciences. \\ Hochschule Lausitz, Germany
}

\begin{abstract}
Climate change is underway and the rising of oceans and frequency of destroying floods have gone on already in a considerable way. The level and the waves of the oceans threaten the coastlines. Especially in river districts of many countries we have to note the worst cases of floods. On the other hand, mankind is growing more and more and the right of adequate housing and sufficient space too. In this situation floating houses and floating settlements in coastal regions and flood plains could be the basis for a sustainable city in the future worldwide.

Let us look for a local climate adaption. In this context, a lot of topics must be researched: environmental problems, energy supply, disposal, measurements of boundary conditions (climate and water quality), damage to floating homes, development of new materials, the use of pontoon's volume as a housing or technique room and for storage of energy, goods and materials. Besides climate change, other global changes, such as the migration of people, animals and plants or the influences of industrial and financial activities should be considered too. Keywords: climate change, floods, urban strategies, floating house.
\end{abstract}

\section{Introduction}

Climate change is causing a global sea-level rise - that is a fact. Nowadays these are only some centimeters per year, but in the next decades it will be much more, fig.1. The effects of future sea-level rise on coastal zones are one of the problems, which must be tackled in the near future. For example, some coastal areas of the North Sea in Germany or in Southeast Asia in the future lie below sea level. In a magazine article [1] the economic real estate risk is assessed for 


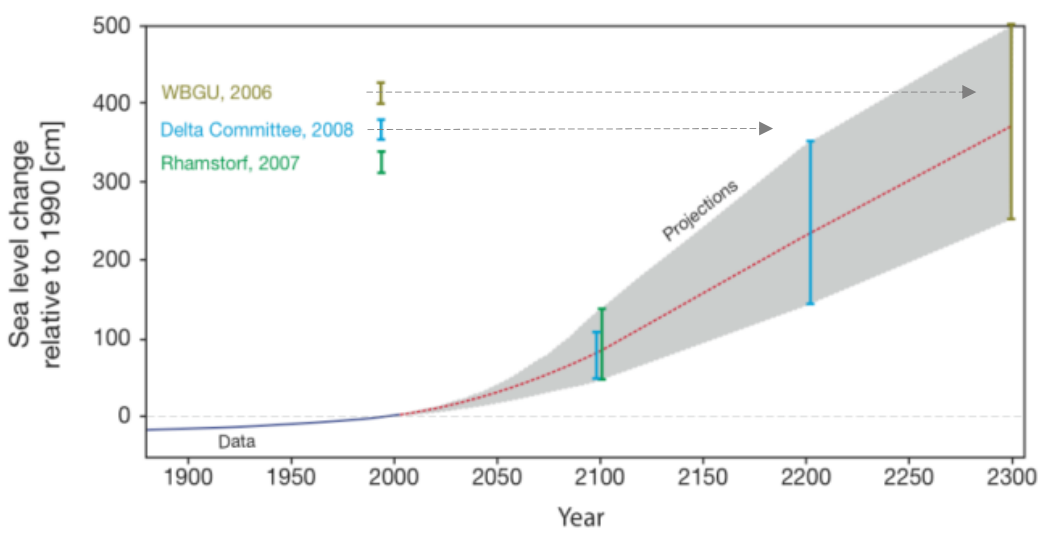

Figure 1: $\quad$ Forecasts of the rise of sea levels [3].

the second largest city Aarhus in Denmark based on an accurate model and highly computationally efficient flooding algorithm. A resolution worldwide could be floating houses. Progressive architects deal with this topic and demonstrate examples of floating settlements all over the world [2].

Research groups already exist in some German districts; investigating the special chances and risks of floating architecture in context with the export of such architecture. Besides the use of floating houses for tourism and housing on post-opencasts mining lakes is investigated. Different topics are discussed, such as alternative energies, room-climate, supply, material-test, disposal, waste, social behaviour, design, safety and security and the development and application of pontoons. The $3^{\text {rd }}$ International Conference on Flood Recovery, Innovation and Response took place in Dubrovnik in 2011. The conference deals with flood risk analysis, critical infrastructure protection and flood consequence assessment. It would be helpful to transfer the ideas and discussion of this paper to the conference in Croatia too. In the same way, it is appropriate for the Conference on Environmental Impact 2012 in New Forest, UK.

\section{Global situation}

All over the world architects are looking ahead for innovative projects on water surfaces, fig. 2. A floating home, made of wood including the basement, has been installed on Lake Weißensee in Austria, fig. 3. Its special ability consists of turning to the desired position according to the sun. The mosque shown in fig. 6, designed by the well known Waterstudio of the architect Olthuis in the Netherlands, is constantly cooled by water running over the outer surface of the envelope. 


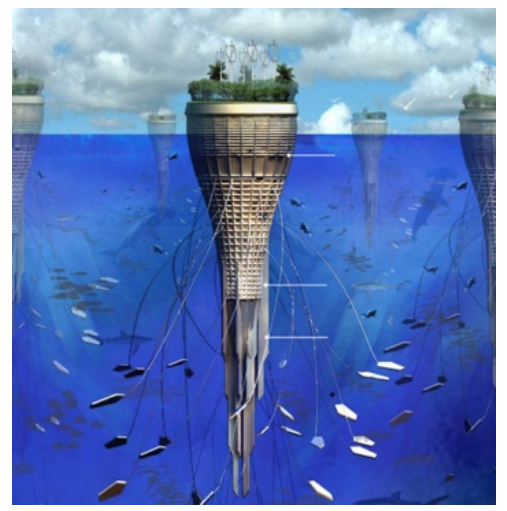

Figure 2: $\quad$ Floating autonomous cities with independent living spaces [2].

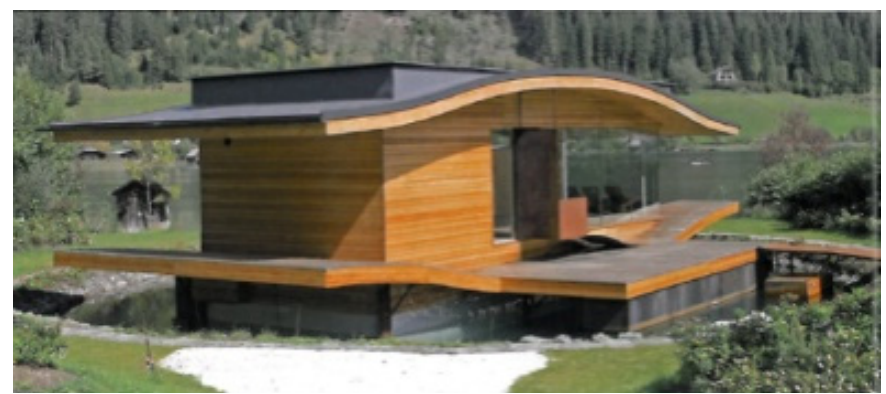

Figure 3: $\quad$ Floating house at Lake "Weißensee", Austria [4].

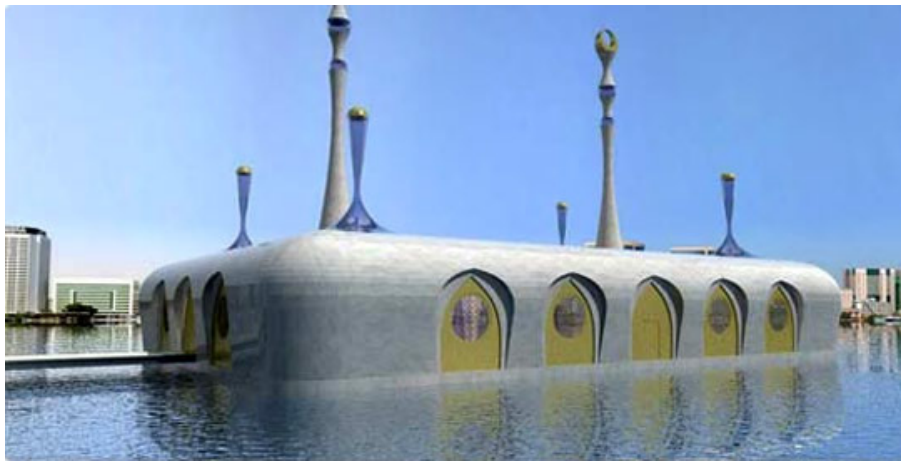

Figure 4: $\quad$ Mosque planned for Dubai, designed by Waterstudio, NL.

\section{German experimental fields for floating houses}

In catalogues, a lot of floating houses are offered. In most cases these exclusive examples are not appropriate for a general settlement of water areas. But they 
can provide assistance for the start into a new era. In the present situation it is necessary to develop different types of floating houses suitable for different locations with regard to climate, water-chemistry, social und natural environment. And we have to gain sufficient experience in order to find practical solutions.

\subsection{Lusatian landscape}

In the Lusatian mining area a field of experiments for floating buildings shall be created. For this reason an institute for floating architecture will be founded in April 2012.

Figure 5 shows the erection of a floating house at the shore of the Lake "Geierswalder See". Up to now two floating houses of the type "Ar-che" are located in the marina. Other erected floating houses in this landscape are used as a holiday house (Partwitzer See, fig. 6) and diving school (Gräbendorfer See, fig. 7).

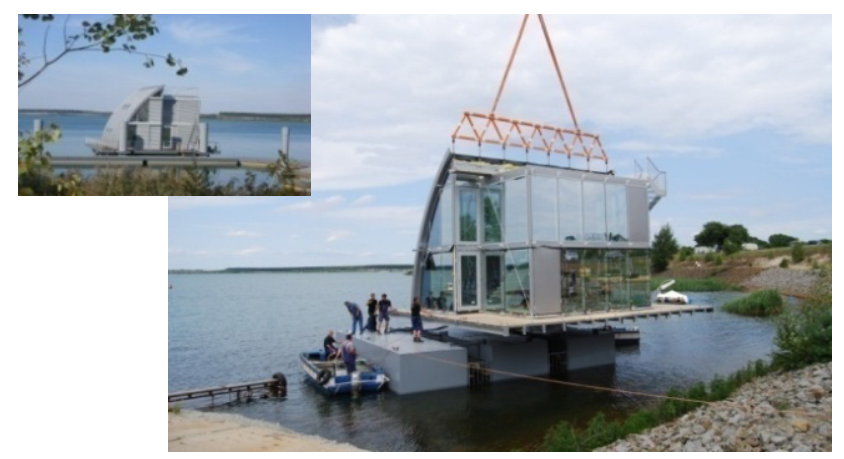

Figure 5: Assembling of a floating house at the shore of Lake "Geierswalder See" in 2009.

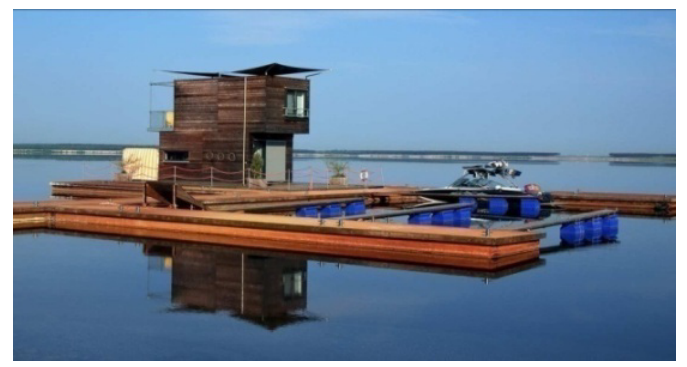

Figure 6: Floating house used as a holiday house at the shore of Lake "Partwitzer See". 


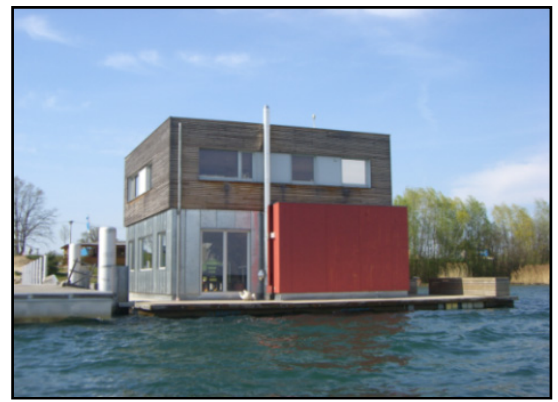

Figure 7: Diving school on Lake "Gräbendorfer See" in the summertime, viewed from the water side.

\subsection{Central Germany and district of river Rhine}

A so-called floating research station was opened in Spring 2011 at a gravel lake near the river Rhine, fig. 8. A project to colonize the water, including the riparian zone is in the planning stage. In memorial to flooded villages due to opencast mining in the Central Germany's mining area, a floating church was installed at Lake "Störmthaler See" near the town Leipzig, fig. 9.

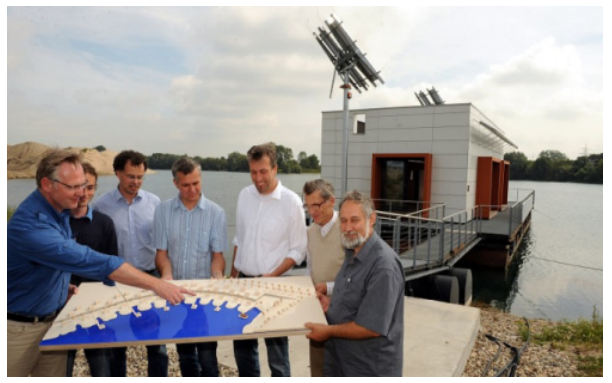

Figure 8: $\quad$ Research station near Kleve at the Lower Rhine [5].

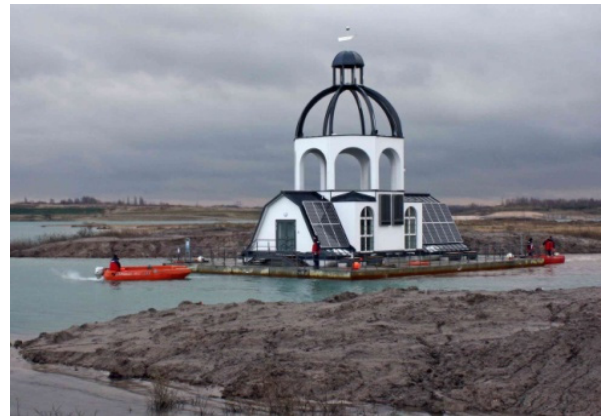

Figure 9: Floating church installed 2010 in the area of "Neuseenland" near the well-known German town Leipzig [6]. 


\subsection{Mobile floating houses}

Besides the ability of floating houses to turn in a desired position according to the sun or neighbourhood, another advantage of such buildings is their mobility. A design competition on "mobile floating architecture" run by the IBA "FürstPückler-Land" in the eastern part of Germany in 2008 was greeted with great interest among experts on a global scale, figs. 10 and 11.

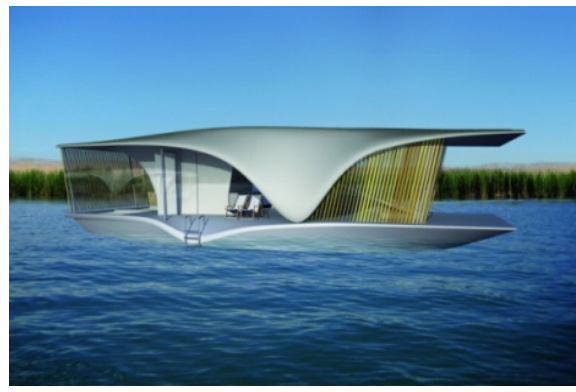

Figure 10: Draft planning, "The Last Resort" by R. Schmidt/ Zürich, CH By R. Schmidt/ Zürich.

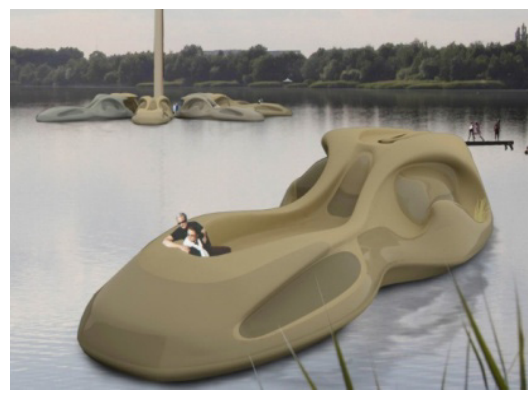

Figure 11:Draft planning "Coalibri” by MIR-architects, NL.

\section{Boundary conditions}

\subsection{Outdoor-indoor climate}

\section{Wintertime}

Figure 12 demonstrates the necessity to guarantee comfort and safety throughout the whole year. During the cold season this demand can be fulfilled by means of heating and a good insulated envelope of buildings, controlled by high-tech solutions, e.g. thermographic examination.

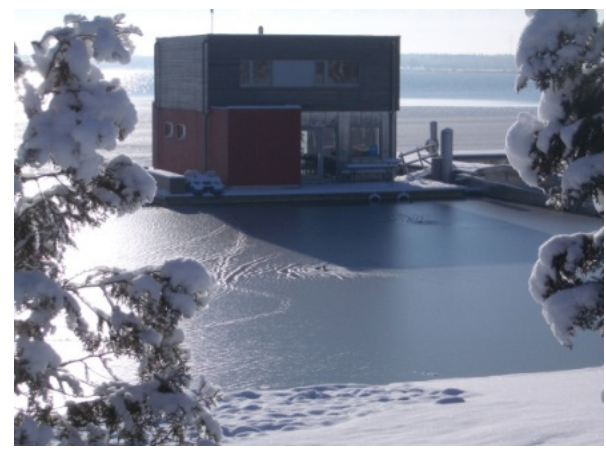

Figure 12: Diving school of figure 7 in wintertime. 


\section{Summmertime}

In contrast to the cold season there are some problems during summertime to restrict the indoor temperature on a level of comfort. Figures 13-15 demonstrate the courses of temperature recorded during summer periods in different rooms of

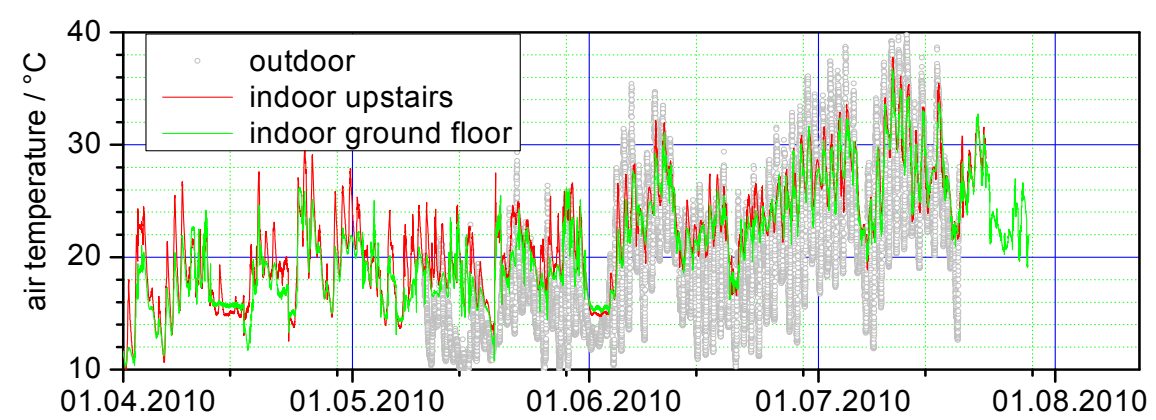

Figure 13: Profile of the outdoor and room air temperatures for the floating house "Ar-che" in the early summer and midsummer of 2010.

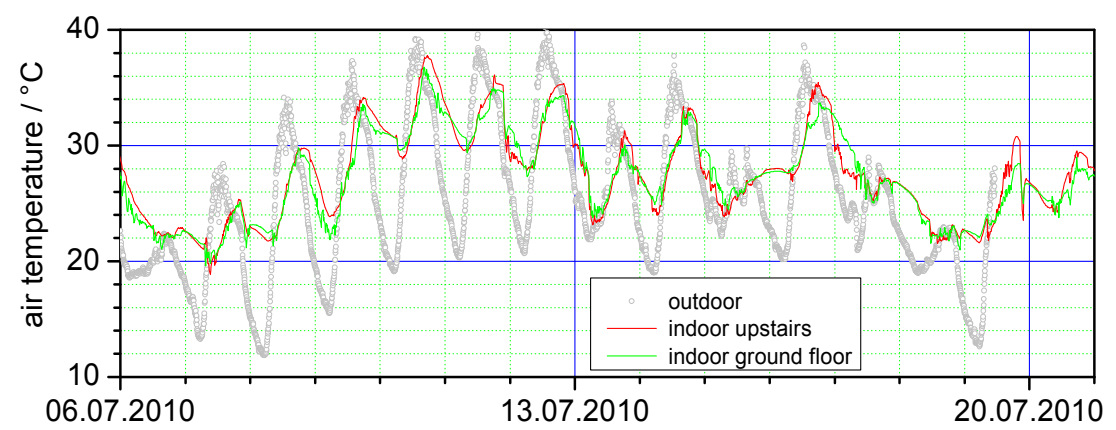

Figure 14: Room air temperature profile of the floating holiday home (fig. 6) in the upper and ground floor during a period of fine weather in July 2010.

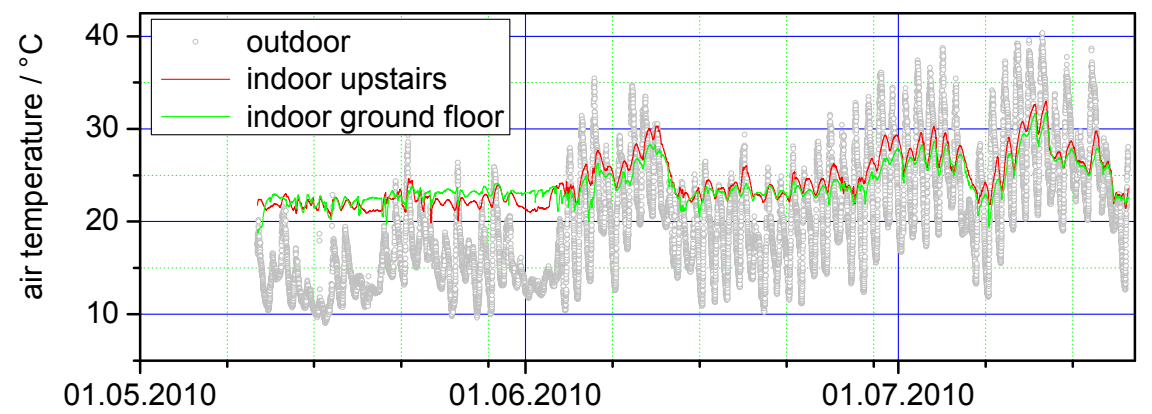

Figure 15: Room air temperature profile of the "Ar-che" (fig. 5) in the upper and ground floor in comparison with the outdoor temperature profile during a period of hot weather in the summer of 2010. 
some floating houses. In this context the methods of cooling by means of water (water envelope or water evaporation, see, e.g., fig. 4) are important in the case of floating houses.

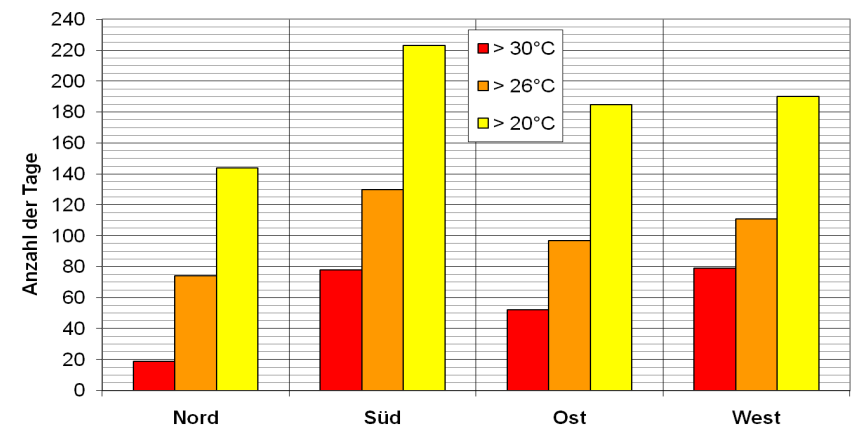

Figure 16: Number of days with cross-border room temperatures in case of four different positions of the balcony of the floating house in fig. 6 .

\subsection{Water quality- water wave}

In addition to the outdoor climate components for the floating houses the physical and chemical properties of water play a crucial role.
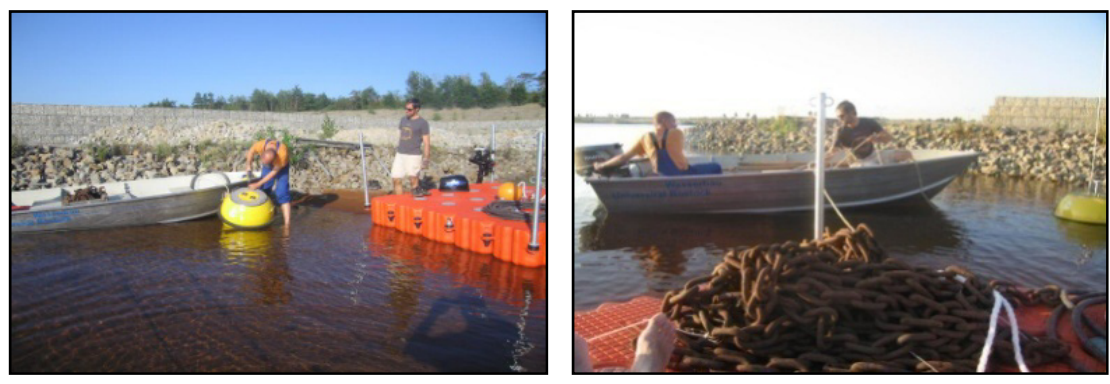

Figure 17: A measuring buoy is floating installed in the position at the "Partwitzer See" in September 2010 in order to record the parameters of waves by means of GPS technology (e.g. fig. 18). 

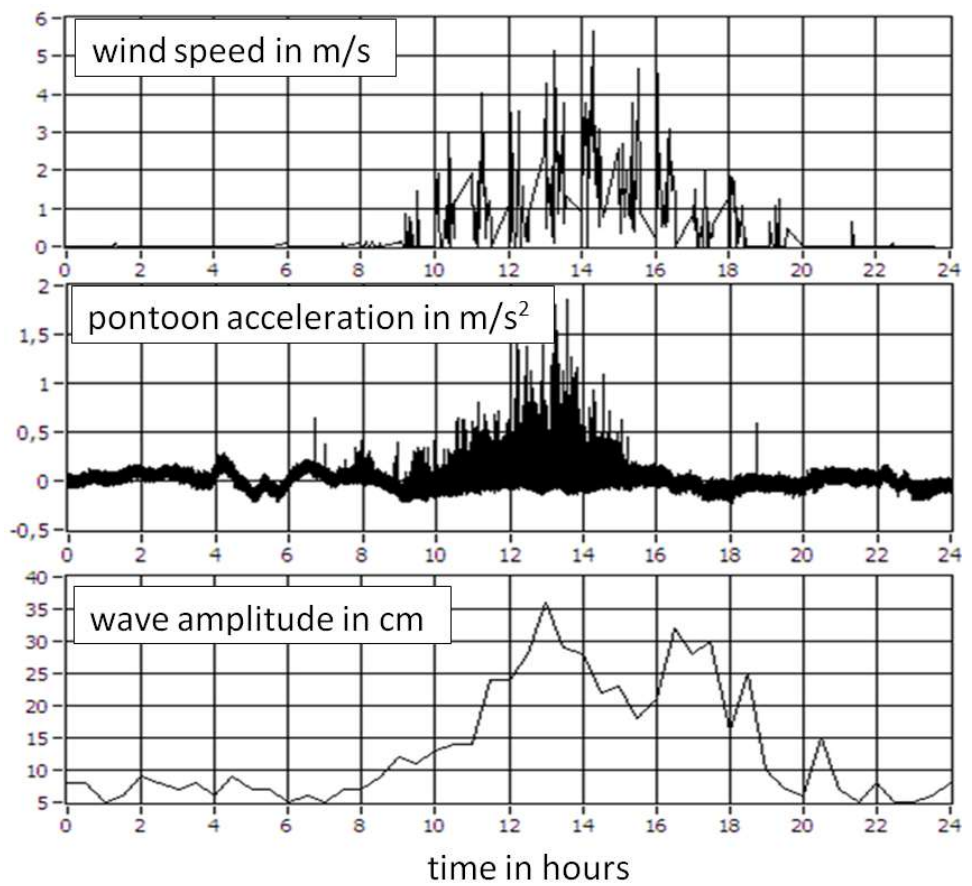

Figure 18: Measuring protocol of wind waves - measuring station concerning wind speed, height of water waves and vibration acceleration of the pontoon on 23.09.2010.

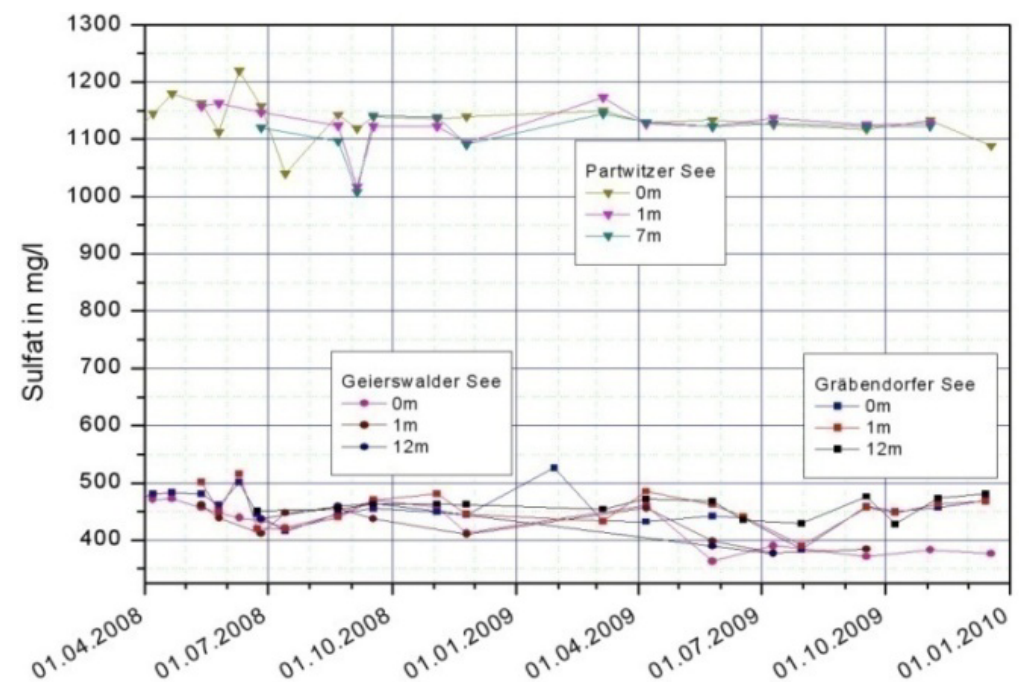

Figure 19: $\mathrm{SO}_{4}$ concentration of three mining lakes with different water depths. 


\section{Potential of pontoons}

\subsection{Floating storage reservoirs}

An innovative application in the future could be floating storage reservoirs. In context with floating settlements they could be installed into the pontoons of floating houses or other floating buildings and constructions.

But it should be possible to develop self-existing floating storage reservoirs too. In this case, the solar energy is added by direct and diffuse radiation collected through a transparent cover. This could be, for example, a thermal insulating window glass with an additional heat insulating blind during the night. The envelope of the reservoir is thermally insulated from the surrounding water. The capacity can be enlarged by means of so-called phase change materials. Figure 20 shows the lowering of temperature of a floating water storage reservoir dependent on the mixture of paraffin.

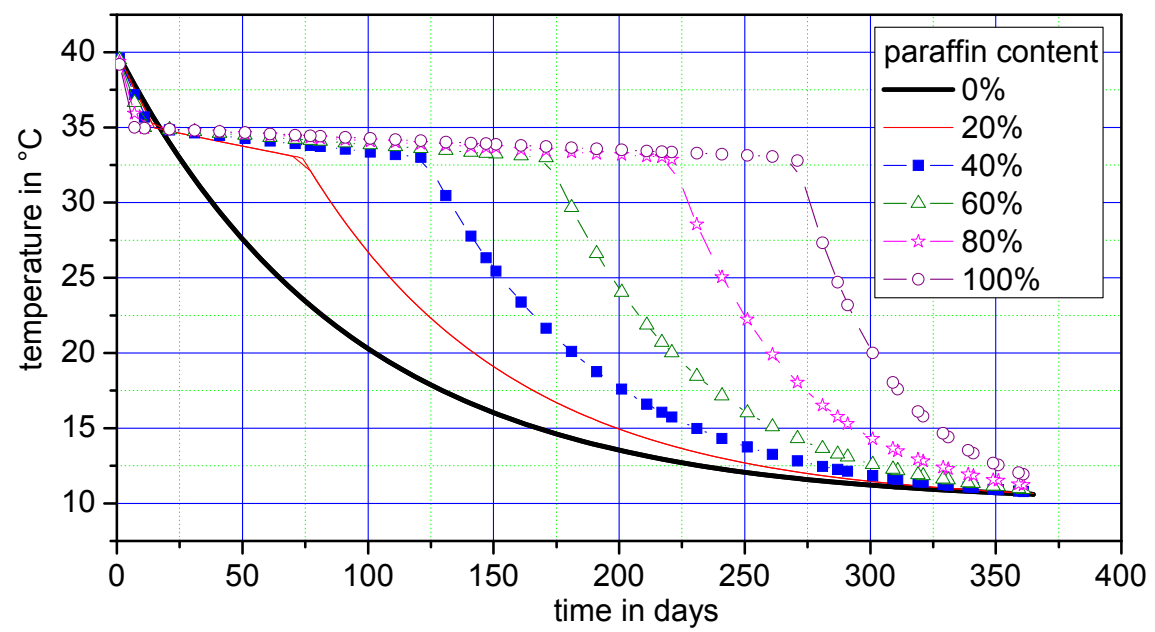

Figure 20: Cooling process of a water tank in dependence of the percentage of phase change materials (PCM) [4].

Besides the application as a storage water reservoir the pontoons can be an additional magazine for goods and wares or even a room for residence. In these cases, the room climate conditions are an important parameter. By means of passive air conditioning, the use of energy can be minimized. Figures 21-22 demonstrate the calculated influence of building materials on the relative humidity of a room (volume $35 \mathrm{~m}^{3}, \mathrm{n}=0,5 \mathrm{~h}^{-1}, \mathrm{~g}=2 \mathrm{~g} / \mathrm{m}^{3} \mathrm{~h}^{-1}, \vartheta_{\mathrm{i}}=21,5^{\circ} \mathrm{C} \pm 1,5 \mathrm{~K}$ ). Figure 23 shows the distribution of moisture in the envelope of an inside insulated steel pontoon calculated by means of numerical simulation. 


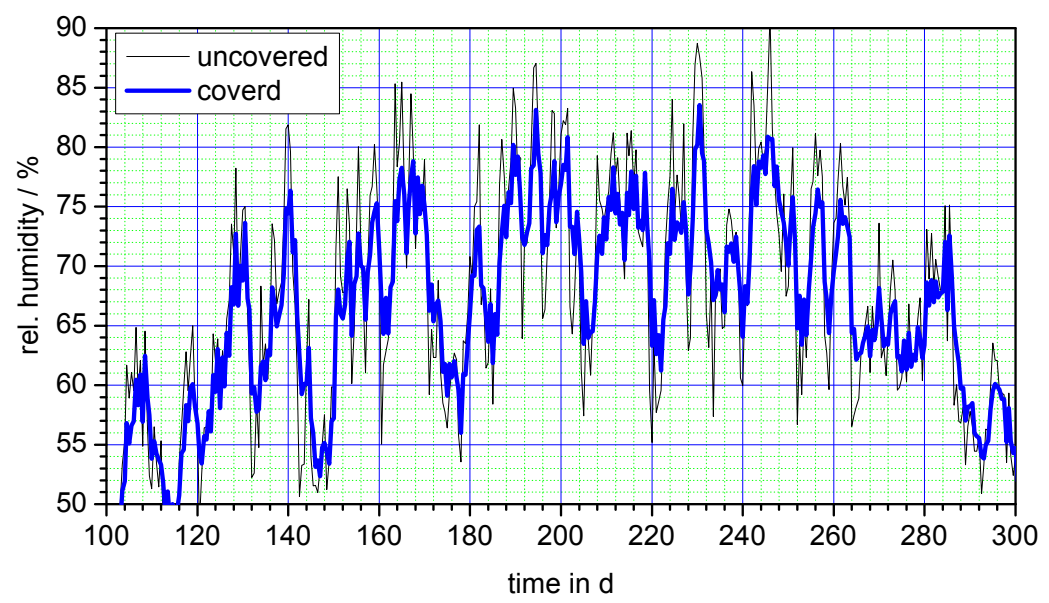

Figure 21: Comparison of the room air humidity between paneled and not paneled internal insulation made of foam glass.

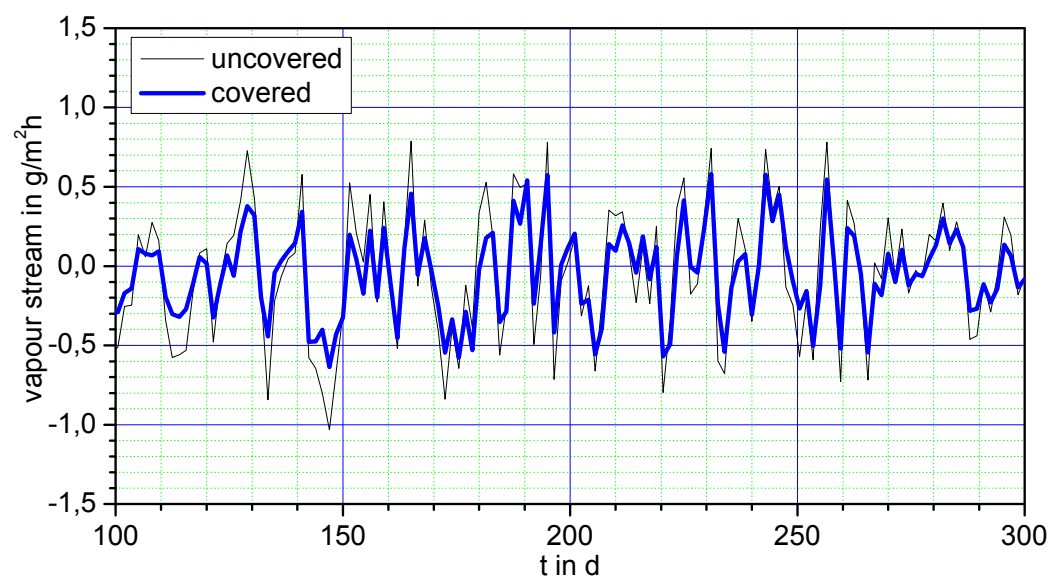

Figure 22: Comparison of moisture flows at the interior wall-surface between paneled and not paneled internal insulation made of calcium silicate. 


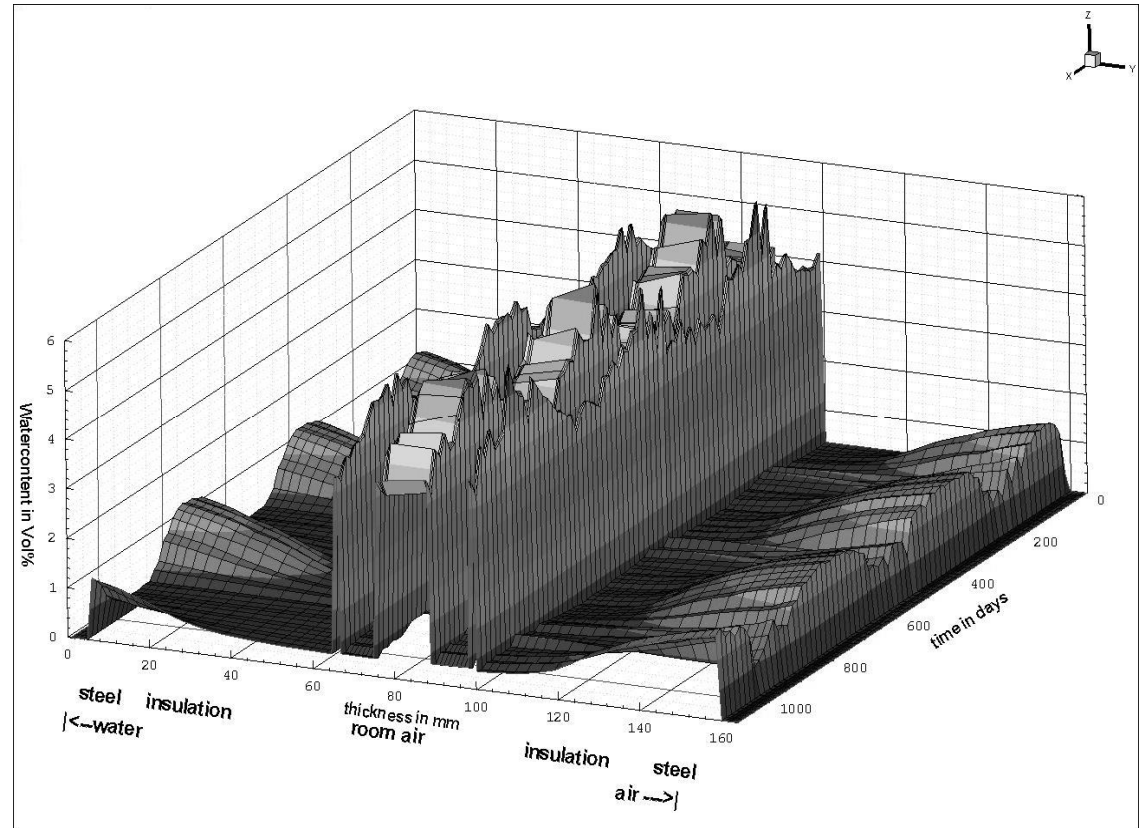

Figure 23: Comparison of the humidity distribution of a steel pontoon in cross-section (internal insulation with calcium silicate $1,0 \mathrm{~m}^{2} \mathrm{~K} / \mathrm{W}$, paneled with gypsum board) with different external conditions (flanking water $12^{\circ} \mathrm{C} \pm 8$ on the left and external air above the water line on the right side) and uniformly fluctuating yearly room air temperature.

\section{References}

[1] Arge, L., Bocher, P.K., Moeslund, J.E., Molhave, T., Svenning, J.C., Impacts of 21 st century sea-level rise on a Danish major city -an assessment based on fine-resolution digital topography and a new flooding algorithm, IOP Conf. Series: Earth and Environmental Science 8, 2009.

[2] ACO Severin Ahlmann GmbH \& Co. KG, Schnittstelle-Architektur-Wasser, 2011.

[3] The Copenhagen Diagnosis, 2009: Updating the World on the Latest Climate Science. http://www.copenhagendiagnosis.org/ http://www.globalwarmingart.com/wiki/Sea_Level_Rise_Maps_Gallery

[4] Harnath, M., Heating and water supply of floating houses in compliance with energy issues, Master's thesis, University of Appl. Sciences, Hochschule Lausitz (FH), 2011.

[5] Hülsmann \& Thieme, Design: Architectural firm, D- 45533 Kleve, Germany.

[6] Winzer, C.: Vineta is anchored, Journal Monumente, Deutsche Stiftung Denkmalschutz, No. 5/6 June, 2010. 